\title{
Oxidative stress and viability of adipose tissue-derived mesenchymal cell cultures from the omentum of rabbits
}

\section{Estresse oxidativo e instabilidade genômica em culturas de células mesenquimais do tecido adiposo do omento de coelho}

\author{
Saulo Tadeu Lemos Pinto Filho ${ }^{1 *}$; Matheus Pippi da Rosa ${ }^{2}$; \\ Tiago Luis Eilers Treichel'; Fabíola Dalmolin ${ }^{4}$; Alencar Kolinski Machado ${ }^{5}$; \\ Francine Carla Cadoná6; Ivana Beatrice Mânica da Cruz ${ }^{7}$
}

\begin{abstract}
Mesenchymal stem cells are a population of somatic cells found in several tissues of an adult organism, including adipose tissue. Reactive oxygen species (ROS) can cause cellular alterations, including mutagenesis and genomic instability and the development of diseases. Thus, it is important to understand ROS-induced damage to cell macromolecules such as DNA, proteins, and lipids. In this study, we investigated oxidative stress rates and viability of adipose tissue-derived mesenchymal stem cells (ADSCs) from the greater omentum of rabbits. Cell cultures were analyzed at different passages (1-5) using the dichlorofluorescein acetate assay for measuring ROS production and cell viability tests. ROS levels were highest at passage 2 and cell viability was highest at passage 4 .
\end{abstract}

Key words: Cell therapy. MSC. Oryctolagus cuniculus. ROS.

\section{Resumo}

Células-tronco mesenquimais são uma população de células somáticas encontradas em vários tecidos de um organismo adulto, incluindo o tecido adiposo. Espécies reativas de oxigênio (ROS) podem causar alterações celulares, incluindo mutagênese e instabilidade genômica e o desenvolvimento de doenças. Assim, é importante entender o dano induzido pelas EROs às macromoléculas celulares, como DNA, proteínas e lipídios. Neste estudo, investigamos as taxas de estresse oxidativo e viabilidade de célulastronco mesenquimais derivadas do tecido adiposo (ADSCs) a partir do omento maior de coelhos. As culturas celulares foram analisadas em diferentes passagens (1-5) utilizando o ensaio de acetato de diclorofluoresceína para medir a produção de ROS e testes de viabilidade celular. Os níveis de EROs foram mais altos na $2^{\mathrm{a}}$ passagem e a viabilidade celular foi maior na $4^{\mathrm{a}}$ passagem.

Palavras-chave: Terapia celular. CTM. Oryctolagus cuniculus. ERO.

1 Prof., Programa de Pós-Graduação em Medicina Veterinária, Universidade Federal de Santa Maria, UFSM, Santa Maria, RS, Brasil. E-mail: saulovet2011@hotmail.com

2 Discente, Programa de Pós-Graduação em Medicina Veterinária da Universidade Federal do Rio Grande do Sul, UFRGS, Porto Alegre, RS, Brasil. E-mail: matheuspippi@hotmail.com

3 Prof., Universidade de Rio Verde, UniRV, Rio Verde, GO, Brasil. E-mail: tletreichel@gmail.com

4 Prof ${ }^{\text {a }}$, Universidade Federal da Fronteira Sul, UFFS, Realeza, PR, Brasil. E-mail: fabioladalmolinn@gmail.com

5 Prof., Universidade Franciscana, UFN, Santa Maria, RS, Brasil. E-mail: alencarkolinski@gmail.com

6 Prof ${ }^{a}$, Programa de Pós-Graduação em Biociências e Saúde, Universidade do Oeste de Santa Catarina, Unoesc, Joaçaba, SC, Brasil. E-mail: fran.cine.bio@hotmail.com

7 Profa, Programa de Pós-Graduação em Ciências Biológicas: Bioquímica Toxicológica, UFSM, Santa Maria, RS, Brasil. E-mail: ibmcruz@hotmail.com

* Author for correspondence. 


\section{Introduction}

Free radicals are any chemical species capable of independent existence that contain one or more unpaired electrons in their outer electron layer, making them highly unstable and with a short half-life. Reactive oxygen species (ROS) include free radicals such as superoxide $\left(\mathrm{O}_{2}{ }^{--}\right)$, hydroxyl radical $(\bullet \mathrm{OH})$, and peroxyl $\left(\mathrm{RO}_{2}\right)$, as well as nonradical species such as hydrogen peroxide $\left(\mathrm{H}_{2} \mathrm{O}_{2}\right)$ (HALLIWELL; GUTTERIDGE, 2007).

ROS may be formed as by-products of metabolic enzymatic reactions in vivo. However, these reactive molecules are also capable of causing damage to cellular constituents when oxidative imbalance is generated. Mutagenesis, one of the cellular alterations induced by ROS, is associated with cellular aging and development of some diseases such as cancer. Thus, the research field of redox regulation has experienced rapid growth over the last years and numerous research groups have investigated ROS-induced damage to cellular macromolecules, including DNA, proteins, and lipids (DRÖGE, 2002).

Bittencourt et al. (2013) found a dose-dependent increase in oxidative stress in fibroblasts exposed to different concentrations of sodium nitroprusside. In addition, by using a fluorimetric method to measure total levels of ROS with a 2',7'-dichlorofluorescein diacetate probe, the authors described the antioxidant potential of the hydroalcoholic extract of Paullinia cupana Mart., popularly known as guarana, in reducing oxidative imbalance.

Adult mesenchymal stem cells (MSCs) are a small population of cells found primarily in perivascular regions of several tissues of an adult organism, including bone marrow, adipose tissue, periosteum, muscle tissue, and parenchymal organs. In 2001, a pioneer study using MSCs described the presence of MSCs in human lipoaspirates, suggesting that the adipose tissue may represent a potential alternative source of adult stem cells (ZUK et al., 2001). Since then, several studies have described the generation adipose tissue-derived mesenchymal stem cells (ADSCs) from experimental animal models and human tissue (PINTO FILHO et al., 2013).

Several clinical applications for ADSCs, especially those derived from subcutaneous tissue, have been described over the last decade. ADSCs are easily harvested by liposuction under local anesthesia (MIZUNO, 2009; CASTEILLA et al., 2011) and, similarly to bone marrow stem cells, can be differentiated into different mesodermal tissues (MIZUNO, 2009).

However, undesirable epigenetic reprogramming may occur in cultured cells, affecting their differentiation capacity. As a consequence, these cells become susceptible to mutations that will initiate several pro-carcinogenic events such as chromosomal instability and proliferative changes, making the therapeutic use of ADSC cultures not recommended (BAUM et al., 2011).

Pinto Filho et al. (2015) found differences in the proliferative capacity and viability of ADSCs from the greater omentum, perirenal region, and adipose interscapular pouch of rabbits and concluded that harvesting ADSCs from the greater omentum yielded the best results.

PicoGreen ${ }^{\circledR}$ is an ultrasensitive fluorescent reagent that can be used to quantitate lower extracellular double-stranded (ds) DNA concentrations $(\sim 25 \mathrm{pg} / \mathrm{mL})$. Quantification of dsDNA in the extracellular space, as accumulated in culture media after cell passaging, can therefore be used to indirectly evaluate cytotoxicity and viability of cell cultures.

Given the high yield of ADSCs and the scarce literature on cells derived from this type of adipose tissue, the aim of this study was to determine the effect of ROS over oxidative stress rates and viability of ADSCs cultures from the greater omentum of rabbits. Cell cultures were analyzed at different passages (1-5) using the PicoGreen ${ }^{\circledR}$ dsDNA fluorescent dye and the 2'7'-dichlorodihydrofluorescein diacetate (DCFH-DA) assay. 


\section{Material and Methods}

\section{Animal experimentation}

This study was approved by the Ethics Committee on Animal Use at the Federal University of Santa Maria (UFSM), Rio Grande do Sul, Brazil, under protocol number 060/2012.

Three clinically healthy adult male New Zealand White rabbits (Oryctolagus cuniculus) weighing $3.39 \pm 0.27 \mathrm{~kg}$ obtained from the UFSM Central Animal Facility were used in the study. Rabbits (C1, C2 and C3) were housed in individual cages in a temperature-controlled room for a minimum 15day acclimation period and monitored for any sign of illnesses, morbidity or mortality. Rabbits were given free access to commercial food and water throughout the study.

After the observational period, surgeries were conducted under general anesthesia by a veterinary team. Following a retro-umbilical midline laparotomy, major omentum was excised by blunt dissection and adequate hemostatic maneuvers. Muscular and subcutaneous suture was performed using 3-0 polyglactin 910 sutures, followed by skin suture with 4-0 nylon sutures. During the post operatory period, analgesic and anti-inflammatory drugs were applied.

\section{Cell isolation and culture}

The excided omentum was stored in sterile flasks containing $150 \mathrm{~mL}$ of Hanks' solution. Samples were treated with type II collagenase to isolate ADSCs following the protocol outlined by Buehrer and Cheatham (2013). Cells were transferred to $75-\mathrm{cm}^{2}$ DNAse and RNAse free, non-pyrogenic cell culture flasks (Kasvi ${ }^{\circledR}$, São José dos Pinhais, PR, Brazil) filled with $10 \mathrm{~mL}$ of Dulbecco's Modified Eagle Medium (DMEM) (Sigma-Aldrich ${ }^{\circledR}$, St. Louis, MO, USA) supplemented with $10 \%$ fetal bovine serum (FBS) (Sigma-Aldrich ${ }^{\circledR}$ ), 1\% penicillin/ streptomycin and amphotericin B (Sigma-Aldrich ${ }^{\circledR}$ ). Cells were incubated at $37{ }^{\circ} \mathrm{C}$ and an atmosphere of $5 \% \mathrm{CO}_{2}$. When monolayer cultures reached 90$95 \%$ confluence, cells were split and cultured in new flasks until the fifth passage. Cell proliferation and viability and oxidative stress parameters were evaluated at each passage.

\section{In vitro assays}

To assess proliferation of ADSCs, cells were stained with trypan blue $(1: 1, \mathrm{v}: \mathrm{v})$ and counted using a Neubauer Chamber. Cell count at all passages was determined in four quadrants under a microscope at $100 \times$ magnification.

Total ROS levels were measured using 2'7'-dichlorodihydrofluorescein diacetate (DCFHDA), which is the most widely used probe for detecting hydrogen peroxide $\left(\mathrm{H}_{2} \mathrm{O}_{2}\right)$. DCFH-DA crosses the cell membrane and is hydrolyzed by intracellular esterases to 2 ' 7 ''-dichlorodihydrofluorescein, which is oxidized to highly fluorescent dichlorofluorescein (DCH) in the presence of cellular ROS. Briefly, $50 \mu \mathrm{L}$ of each sample of ADSCs was incubated in a 96-well dark plate with $10 \mathrm{mM}$ Tris $\mathrm{HCl}$ buffer and DCFH-DA for $1 \mathrm{~h}$ as described by Ahn et al. (1996). Fluorescence was measured at 488-nm excitation wavelength and 525-nm emission wavelength on a SpectraMax plate reader (Molecular Devices, San José, CA, USA).

Extracellular dsDNA was quantified using PicoGreen $^{\circledR} \quad$ (Invitrogen/Life Technologies, Carlsbad, CA, USA), which has high affinity for dsDNA. Samples were incubated with the fluorescent dye diluted in $1 \mathrm{X}$ TE buffer (1:200; $\mathrm{v}: \mathrm{v})$ following the manufacturer's instructions. Fluorescence was measured at 480-nm excitation wavelength and 520-nm emission wavelength on a SpectraMax plate reader (Molecular Devices).

\section{Flow cytometry}

The expression of ADSCs markers was characterized by flow cytometry. Cells were fixed 
with 4\% paraformaldehyde diluted in $1 \mathrm{X}$ PBS for 20 min. Next, samples were blocked with 1X PBS buffer containing 3\% FBS for $20 \mathrm{~min}$ and incubated with anti-CD105 PerCPCy5.5, anti-CD90 PE, anti-CD45 FITC, and anti-CD73 FITC antibodies at a dilution of 5:100, 5:100, 20:100, and 10:100, respectively, for $30 \mathrm{~min}$ at room temperature. Samples were then washed and resuspended with 1X PBS for flow cytometry data acquisition using BD FACSDiva ${ }^{\mathrm{TM}}$ (BD Biosciences, Franklin Lakes, NJ, USA). A minimum of 300,000 cells gated according to the Forward scatter (FSC) and Side scatter (SSC) parameters were analyzed per sample. Flow cytometry data were analyzed using FlowjoV10 software.

\section{Statistical analysis}

All data were plotted using Microsoft Excel 2010 software. Data are expressed as percent of viable cells at first passage. Statistical analysis was performed using GraphPad Prism ${ }^{\mathrm{TM}} 5.0$ (GraphPad Software, San Diego, CA, USA). Comparisons were made using one-way analysis of variance (ANOVA) followed by the Dunnett's post hoc test. Differences were considered significant when $p<0.05$.

\section{Results and Discussion}

Omentectomy was successfully performed in all rabbits and no technical difficulties were experienced during serial passaging of rabbit ADSCs. Surgical procedure was fast, safe and relatively easy to perform. Singh et al. (2008) proposed an alternative method to collect ADSCs from rat omentum consisting of omental activation by previous intraperitoneal injection of polydextran particles. In their study, omentum ADSCs produced high levels of vascular endothelial growth factor (VEGF), indicating that omental stromal cells are an important source of adult stem cells for cellbased therapies.
The amount of omental tissue varied among rabbits and the amount of excised tissue ranged from $2.0 \mathrm{~g}$ in rabbit $\mathrm{C} 3$ to $3.0 \mathrm{~g}$ in rabbits $\mathrm{C} 1$ and $\mathrm{C} 2$ (mean $=2.66 \mathrm{~g}$ ). Rabbits $\mathrm{C} 1, \mathrm{C} 2$, and $\mathrm{C} 3$ weighed $3.67,3.12$, and $3.38 \mathrm{~kg}$, respectively, at the time of surgery, indicating that the amount of omental tissue excised was not affected by animals' body weights. Conversely, Ribeiro et al. (2012) reported that the amount of fat tissue excised varied among horses (mean $=13.44 \mathrm{~g}$ of fat tissue per animal).

The amount of omental tissue excised in our study was sufficient for isolating and culturing ADSCs. Cell proliferation decreased between the first and second passages and increased in the third passage. Similar to our results, Kern et al. (2006) reported that human ADSCs showed the highest proliferation capacity between the third and sixth passages. In our study, most ADSC cultures exhibit a similar proliferation pattern, which may be explained by the length of time required for adaptation to in vitro conditions and the optimal cell concentration for fast culture growth. Mean cell concentration across passages was $1,423,372$ cells per gram of adipose tissue.

No significant differences in cell viability were detected between the five passages $(94.27 \pm 0.07 \%$, p $=\mathrm{ns})$. Similar results were reported by Heimburg et al. (2004) and Ribeiro et al. (2012), who found high cell viability in human preadipocytes cultured from excised or aspirated adipose tissue (94\%) and fatty gluteal tissue of horses (96\%), respectively.

The dichlorodihydrofluorescein diacetate (DCFH-DA) assay showed that total ROS production was lower at passages 3-5 of cells derived from rabbits $\mathrm{C} 1$ and $\mathrm{C} 2$. In addition, ROS production was significantly different between passages 1-2 of cells derived from rabbit $\mathrm{C} 1$. Moreover, ROS production was highest in the second passage in the three animals, which may be related to the lowest proliferation rate observed at passage 2 (Figure 1A). 
Figure 1. (A) ROS production according to the DCFH-DA assay. Note the lower ROS levels at passages 3-5 in cells derived from rabbits $\mathrm{C} 1$ and $\mathrm{C} 2$. (B) Quantitation of dsDNA using PicoGreen ${ }^{\circledR}$ fluorescent dye. Note the reduced cytotoxicity at passage 4 compared to passage 1 in cells derived from rabbits $\mathrm{C} 2$ and $\mathrm{C} 3{ }^{*}{ }^{* * *}(\mathrm{p}<0.0001),{ }^{* *}(\mathrm{p}<0.001)$, and $*(\mathrm{p}<0.05)$.

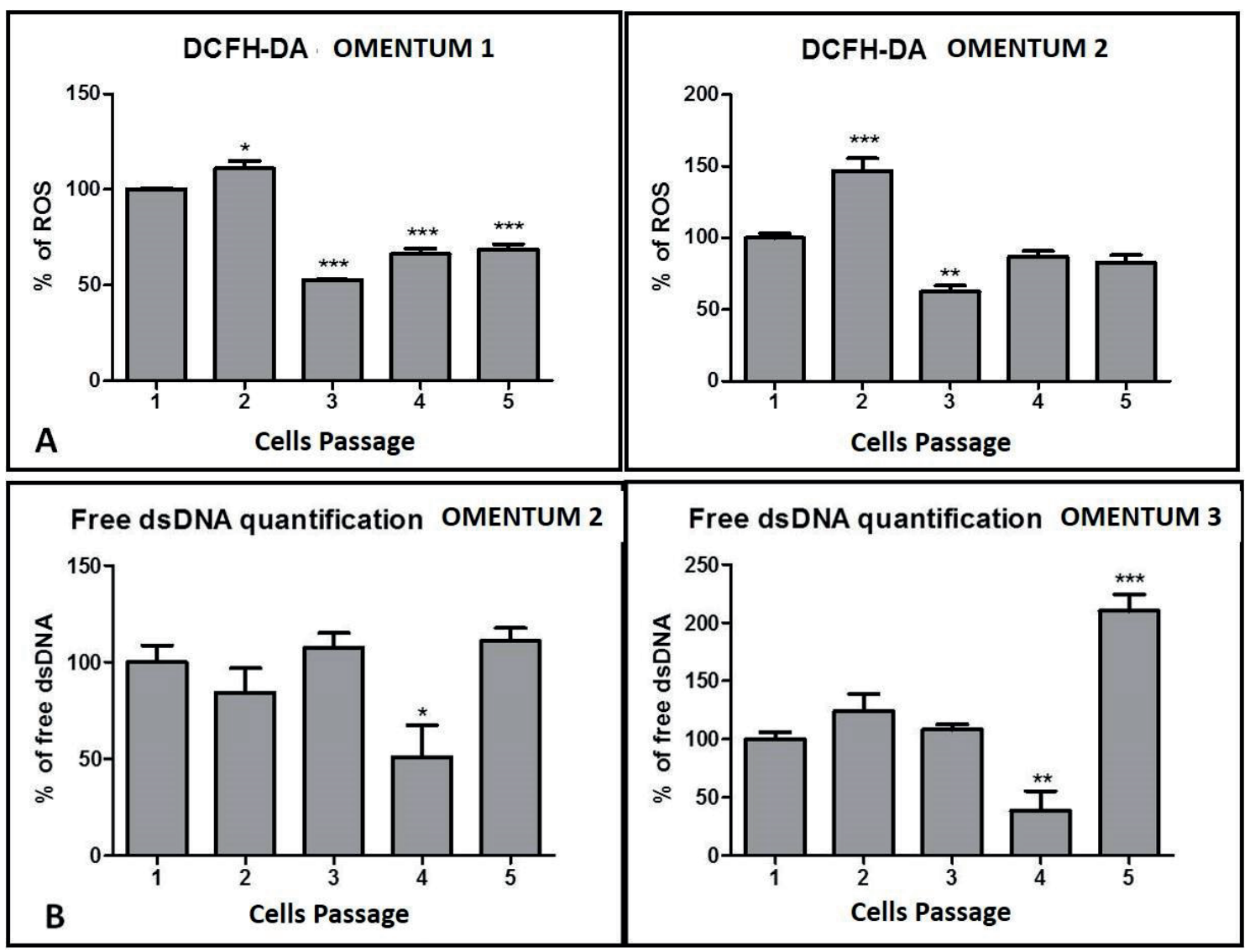

Chen et al. (2006) evaluated oxidative stress in irradiated human bone marrow-derived MSCs after two passages by DCFH-DA fluorescence and reported that the intracellular level of ROS increased after irradiation. Even though other studies used DCFH-DA to assess oxidative stress in MSCs from other sources (RAFFAGHELLO et al., 2008; TAYEB et al., 2010) and cell types such as fibroblasts (BITTENCOURT et al., 2013), to the best of our knowledge, ours is the first study to investigate oxidative stress in ADSCs from the greater omentum of rabbits.

The PicoGreen ${ }^{\circledR}$ dsDNA quantitation assay showed that the amount of free DNA in the extracellular space of ADSCs cultures was significantly smaller at passage 4 compared to passage 1 in cells derived from rabbits $\mathrm{C} 2$ and $\mathrm{C} 3$, indicating cytotoxicity. However, the amount of free DNA increased at passage 5, indicating there was greater cell damage compared to passages 1-4 (Figure 1B). Conversely, Aramburú Júnior (2013) reported higher cell proliferation and less DNA fragmentation, as detected by PicoGreen ${ }^{\circ}$, at passages 1-3 in canine dental pulp-derived MSCs (ARAMBURÚ JÚNIOR, 2013).

In 2006, the International Society for Cellular Therapy proposed a set of minimum criteria to define mesenchymal stromal cells (MSC). First, MSC must be plastic-adherent when maintained in standard culture conditions using tissue culture flasks. Second, MSC must express CD105, CD73, and CD90 and lack expression $(\leq 2 \%)$ of CD34, 
CD45, CD14 or CD11b, CD79a or CD19, and HLA-DR surface molecules (BYDLOWSKI et al., 2009; TORRES, 2009; MONTEIRO et al., 2010; CARVALHO et al., 2013; XU et al., 2015). Third, MSCs must be able to differentiate into osteocytes, adipocytes, and chondrocytes in vitro (DOMINICI et al., 2006). In the current study, human-specific anti-CD105, anti-CD90, and anti-CD73 antibodies were used as positive controls for ADSCs in flow cytometry analyzes, whereas human-specific anti-
CD45 was used as a negative control. Even though the antibodies used were not specific for rabbit cells, they were able to detect rabbit proteins. In our study, rabbit ADSCs expressed CD105, CD73, and CD90 and adhered to plastic flasks during culture (Figure 2), In addition, the cell population was homogeneous in size and granularity (Figure 2B). Similar results were reported by Torres (2009) for cells derived from interscapular fat pouch tissue of New Zealand White rabbits.

Figure 2. (A) Adipose tissue-derived stem cells (ADSCs) from the greater omentum of New Zealand White rabbits during the expansion period at $37^{\circ} \mathrm{C}$ in $\mathrm{CO}_{2}$. Note the fibroblastoid morphology at day 10 of culture. (B) Cell clustering by cell size and granularity. Note the homogeneity of the cell population.
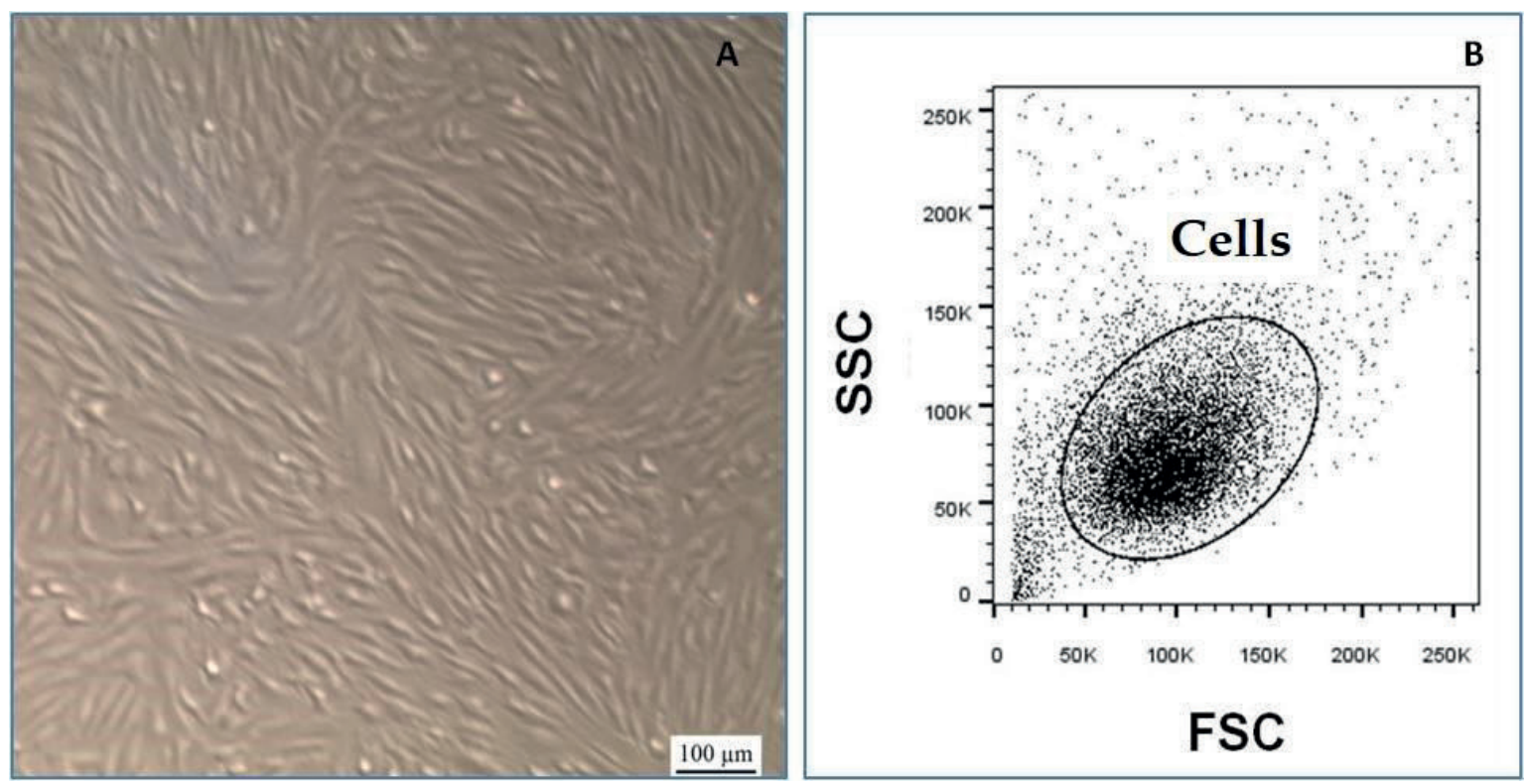

\section{Conclusion}

ROS production was highest at passage 2 and cell viability was lowest at passage 4 of rabbit adipose-tissue-derived mesenchymal stem cells.

\section{Acknowledgments}

The authors thank Coordenação de Aperfeiçoamento de Pessoal de Nível Superior (CAPES) for financial support.

\section{References}

AHN, S. J.; COSTA, J.; EMANUEL, J. R. PicoGreen quantification of DNA: effective evaluation of samples pré- or post-PCR. Nucleic Acids Research, Oxford, v. 24, n. 13, p. 2623-2625, 1996. Available at: <http://nar. oxfordjournals.org/content/24/13/2623.short $>$. Accessed at: 20 nov. 2014.

ARAMBURÚ JÚNIOR, J. S. Isolamento e análise de danos genômicos de células-tronco da polpa dentária de cães. 2013. Dissertação (Mestrado em Medicina Veterinária) - Programa de Pós-Graduação em Medicina Veterinária, Universidade Federal de Santa Maria, Santa Maria. 
BAUM， C.; MODLICH， U.; GÖHRING， G.; SCHLEGELBERGER, B. Concise review: managing genotoxicity in the therapeutic modification of stem cells. Stem Cells, Durham, v. 29, p. 1479-1484, 2011. Available at: $\quad<$ http://onlinelibrary.wiley.com/doi/10.1002/ stem.716/full>. Accessed at: 21 nov. 2014.

BITTENCOURT, L. S.; MACHADO, D. C.; MACHADO, M. M.; SANTOS, G. F. F. dos; ALGARVE, T. D.; MARINOWIC, D. R.; RIBEIRO, E. E.; SOARES, F. A. A.; BARBISAN, F.; ATHAYDE, M. L.; CRUZ, I. B. M. The protective effects of guaraná extract (Paullinia cupana) on fibroblast NIH-3T3 cells exposed to sodium nitroprusside. Food and Chemical Toxicology, Atlanta, v. 53, p. 119-125, 2013. Available at: <http://www.sciencedirect.com/science/article/pii/ S0278691512008484>. Accessed at: 21 nov. 2014.

BUEHRER, B. M.; CHEATHAM, B. Isolation and characterization of human adipose-derived stem cells for use in tissue engineering. Methods in Molecular Biology, New York, v. 1001, p. 1-11, 2013. Available at: <http://link. springer.com/protocol/10.1007/978-1-62703-363-3>. Accessed at: 21 nov. 2014.

BYDLOWSKI, S. P.; DEBES, A. A.; MASELLI, L. M.; JANZ, F. L. Características biológicas das células-tronco mesenquimais. Revista Brasileira de Hematologia e Hemoterapia, Rio de Janeiro, v. 31, n. 1, p. $25-$ 35, 2009. Disponível em: <http://www.scielo.br/pdf/ rbhh/2009nahead/aop3809>. Acesso em: 20 nov. 2014.

CARVALHO, A. M.; YAMADA, A. L. M.; GOLIM, M. A.; ÁlVAREZ, L. E. C.; JORGE, L. L.; CONCEIÇÃO, M. L.; DEFFUNE, E.; HUSSNI, C. A.; ALVES, A. L. G. Characterization of mesenchymal stem cells derived from equine adipose tissue. Arquivo Brasileiro de Medicina Veterinária e Zootecnia, Belo Horizonte, v. 65, n. 4, p. 939-945, 2013. Available at: <http://dx.doi. org/10.1590/S0102-09352013000400001>. Accessed at: 21 nov. 2014.

CASTEILLA, L.; PLANAT-BERNARD, V.; LAHARRAGUE, P.; COUSIN, B. Adipose-derived stromal cells: their identity and uses in clinical trials, an update. World Journal Stem Cells, Plesanton, v. 3, n. 4, p. 25-33, 2011. Available at: <http://www.ncbi.nlm.nih. gov/pubmed/21607134>. Accessed at: 21 nov. 2014.

CHEN, M. F.; LIN, C. T.; CHEN, W. C.; YANG, C. T.; CHEN, C. C.; LIAO, S. K.; LIU, J. M.; LU, C. H.; LEE, K. D. The sensitivity of human mesenchymal stem cells to ionizing radiation. International Journal of Radiation Oncology Biology Physics, Philadelphia, v. 66, n. 1, p. 244-253, 2006. Available at: <http://www. sciencedirect. com/science/article/pii/S0360301606006833>. Accessed at: 23 nov. 2014.
DOMINICI, M.; LE BLANC, K.; MUELLER, I.; SLAPER-CORTENBACH, I.; MARINI, F.; KRAUSE, D.; DEANS, R.; KEATING, A.; PROCKOP, D. J.; HORWITZ, E. Minimal criteria for defining multipotent mesenchymal stromal cells. The International Society for Cellular Therapy position statement. Cytotherapy, Philadelphia, v. 8, n. 4, p. 315-317, 2006.

DRÖGE, W. Free radicals in the physiological control of cell function. Physiological Reviews, Alabama, v. 82, n. 1, p. 47-95, 2002. Available at: <http://physrev. physiology.org/content/82/1/47.short>. Accessed at: 21 nov. 2014.

HALLIWELL, B.; GUTTERIDGE, J. C. Free radicals in biology and medicine. $4^{\text {th }}$ ed. New York: Oxford University, 2007. $851 \mathrm{p}$.

HEIMBURG, D. V.; HEMMRICH, K.; HAYDARLIOGLU, S.; STAIGER, H.; PALLUA, N. Comparison of viable cell yield from excised versus aspirated adipose tissue. Cells Tissues Organs, Basel, v. 178, n. 2, p. 87-92, 2004. Available at: <http://www. karger.com/Article/Fulltext/81719>. Accessed at: 21 nov. 2014.

KERN, S.; EICHLER, H.; STOEVE, J.; KLÜTER, H.; BIEBACK, K. Comparative analysis of mesenchymal stem cells from bone marrow, umbilical cord blood, or adipose tissue. Stem Cells, Durham, v. 24, p. 1294-1301, 2006. Available at: <http://onlinelibrary.wiley.com/ doi/10.1634/stemcells.2005-0342/full>. Accessed at: 25 nov. 2014.

MIZUNO, H. Adipose-derived stem cells for tissue repair and regeneration: ten years of research and a literature review. Journal of Nippon Medical School, Tokyo, v. 76, n. 2, p. 56-66, 2009. Available at: <http://www.jstage.jst. go.jp/article/jnms/76/2/76_2_56>. Accessed at: 25 nov. 2014.

MONTEIRO, B. S.; ARGOLO NETO, N. M.; DEL CARLO, R. J. Células-tronco mesenquimais. Ciência Rural, Santa Maria, v. 40, n. 1, p. 1-8, 2010. Disponível em: <http://submission.scielo.br/index.php/cr/ article/ viewFile/11089/1733>. Acesso em: 25 nov. 2014.

PINTO FILHO, S. T. L.; TREICHEL, T. L. E.; ARAMBURU JÚNIOR, J. S.; ROSA, M. B.; BRUN, M. V.; LINHARES, M. T.; RODRIGUES, B. E.; KRAUSE, A.; VAZ, M. A. B.; DALMOLIN, F.; PIPPI, N. L. Proliferação e viabilidade de células tronco derivadas do omento maior, tecido adiposo perirrenal e bolsa adiposa interescapular em coelhos (Oryctolagus cuniculus). Veterinária e Zootecnia, Botucatu, v. 22, n. 4, p. 607618, 2015. Disponível em: <http://www.fmvz.unesp.br/ rvz/index.php/rvz/article/view/889>. Acesso em: 04 set. 2016. 
PINTO FILHO, S. T. L.; TREICHEL, T. L. E.; ARAMBURU JÚNIOR, J. S.; ROSA, M. B.; DALMOLIN, F.; BRUN, M. V.; KRAUSE, A.; PIPPI, N.

L. Células-tronco mesenquimais adultas: características

e aplicações experimentais em animais. Veterinária

e Zootecnia, Botucatu, v. 20, p. 49-59, 2013. Edição Comemorativa. Disponível em: <http://www.fmvz. unesp.br/rvz/index.php/rvz/article/view/578>. Acesso em: 25 jan. 2015.

RAFFAGHELLO, L.; BIANCHI, G.; BERTOLOTTO, M.; MONTECUCCO, F.; BUSCA, A.; DALLEGRI, F.; OTTONELLO, L.; PISTOIA, V. Human mesenchymal stem cells inhibit neutrophil apoptosis: a model for neutrophil preservation in the bone marrow niche. Stem Cells, Durham, v. 26, n. 1, p. 151-162, 2008. Available at: $\quad<$ http://onlinelibrary.wiley.com/doi/10.1634/ stemcells.2007-0416/full>. Accessed at: 25 jan. 2015.

RIBEIRO, G. Viabilidade celular da fração mononuclear da medula óssea e fração vascular estromal do tecido adiposo de equinos após o processo de congelamento e descongelamento. Pesquisa Veterinária Brasileira, Seropédica, v. 32, n. 1, p. 118-124, 2012. Disponível em: <http://repositorio.unesp.br/handle/ 11449/1814>. Acesso em: 25 jan. 2015.

SINGH, A. K.; PATEL, J.; LITBARG, N. O.; GUDEHITHLU, K. P.; SETHUPATHI, P.; ARRUDA, J. A. L.; DUNEA, G. Stromal cells cultured from omentum express pluripotent markers, produce high amounts of VEGF, and engraft to injured sites. Cell Tissue Research, Philadelphia, v. 332, n. 1, p. 81-88, 2008.
TAYEB, K. S.; NOTO, F. K.; SEPAC, A.; SEDLIC, F.; BOSNJAK, Z. J.; LOUGH, J. W.; DUNCAN, S. A. Generation of human induced pluripotent stem cells by simple transient transfection of plasmid DNA encoding reprogramming factors. BMC Developmental Biology, London, v. 10, n. 81, p. 1-10, 2010. Available at: $<$ bmcdevbiol.biomedcentral.com/articles/10.1186/1471213X-10-81>. Accessed at: 25 jan. 2015.

TORRES, F. C. Panículo adiposo interescapular de coelho da espécie Oryctolagus cuniculus como fonte de células-tronco. 2009. Tese (Doutorado em Ciências) Faculdade de Medicina, Universidade de São Paulo, São Paulo.

XU, N.; GUO, S.; WANG, Y.; SUN, Q.; WANG, C. Transplantation of adipose tissue-derived stromal cells promotes the survival of venous-congested skin flaps in rabbit ear. Cell Biochemistry and Biophysics, San Franscisco, v. 71, n. 2, p. 557-563, 2015. Available at: $<$ bmcdevbiol.biomedcentral.com/articles/10.1186/ 1471-213X-10-81>. Accessed at: 10 mar. 2015.

ZUK, P. A.; ZHU, M.; MIZUNO, H.; HUANG, J.; FUTRELL, J. W.; KATZ, A. J.; BENHAIM, P.; LORENZ, H. P.; HEDRICK, M. H. Multilineage cells from human adipose tissue: Implications for cell-based therapies. Tissue Engineering, New York, v. 7, n. 2, p. 211-228, 2001. 